
VOLUME 10 NOMOR 6 DESEMBER 2021

ISSN : 2303-1514 | E-ISSN : 2598-5949

\title{
PENGEMBANGAN MEDIA DIORAMA UNTUK PEMBELAJARAN IPS KELAS IV SEKOLAH DASAR
}

\author{
Nurul Sapitri ${ }^{1}$, Guslinda $^{2}$, Zufriady $^{3}$ \\ ${ }^{1,2,3}$ UniversitasRiau,Pekanbaru,Indonesia \\ ${ }^{1}$ nurul.sapitri1392@student.unri.ac.id, ${ }^{2}$ guslinda@lecturer.unri.ac.id, ${ }^{3}$ zufriady@lecturer.unri.ac.id
}

\section{DEVELOPING DIORAMA MEDIA FOR SOCIAL STUDIES LEARNING AT GRADE IV ELEMENTARY SCHOOL}

\begin{tabular}{|c|c|}
\hline ARTICLE HISTORY & ABSTRACT \\
\hline $\begin{array}{l}\text { Submitted: } \\
\text { 13 Juli } 2021 \\
13^{\text {th }} \text { July } 2021\end{array}$ & $\begin{array}{l}\text { Abstract: This study aimed to develop diorama learning media in social learning for grade IV } \\
\text { elementary schools and to determine the feasibility of diorama media. This research used } \\
\text { research and development }(R \& D) \text { methods using the model } 4 D \text { (Define, Design, Develop, } \\
\text { Disseminate). This development produced a product that has been adapted to the basic } \\
\text { competencies used, namely identifying economic activities and their relationship to the field of } \\
\text { work. Data were collected through questionnaires and trials. The feasibility of diorama } \\
\text { learning media was obtained from the validation results and students' and teachers' responses. } \\
\text { The validation was carried out by media experts and material experts. The trial conducted was } \\
\text { limited to } 23 \text { grade IV elementary school students. The trial results by material experts were in } \\
\text { the very feasible category, and the validation by media experts was in the very feasible } \\
\text { category. Similarly, the validation from media experts obtained a very feasible category. The } \\
\text { results of this research showed that the diorama media was very feasible for social studies } \\
\text { learning at grade IV elementary schools. }\end{array}$ \\
\hline
\end{tabular}

Keywords: diorama learning media; social studies learning

Accepted:

04 November 2021

$04^{\text {th }}$ November 2021

Published:

27 Desember 2021

$27^{\text {th }}$ December 2021

\begin{abstract}
Abstrak: Penelitian ini bertujuan untuk mengembangkan media pembelajaran diorama pada pembelajaran IPS kelas IV sekolah dasar dan mengetahui kelayakan dari media diorama. Penelitian ini menggunakan metode penelitian dan pengembangan atau Reserch and Development $(R \& D)$ dengan menggunakan model $4 D$ (Define, Design, Develop, Diseminate). Penggembangan ini akan menciptakan suatu produk yang telah disesuaikan dengan Kompetensi Dasar (KD) yang digunakan yaitu mengidentifikasi kegiatan ekonomi dan hubungannya dengan bidang pekerjaan. Teknik pengumpulan data pada penelitian dengan cara angket dan uji coba. Kelayakan media pembelajaran diorama diperoleh dari hasil validasi dan respon dari siswa dan guru. Validasi dilakukan oleh ahli media dan ahli materi. Uji coba yang dilakukan yaitu uji coba terbatas kepada 23 siswa kelas IV sekolah dasar. Hasil uji coba oleh validasi materi dengan katagori sangat layak, dan juga validasi ahli media dengan katagori sangat layak. Hasil penelitian yang dikembangkanan ini menunjukan bahwa media diorama untuk pembelajaran IPS kelas IV sekolah dasar sangat layak digunakan dalam pembelajaran.
\end{abstract}

Kata Kunci: media pembelajaran diorama; pembelajaran IPS

\section{CITATION}

Sapitri, N., Guslinda, G., \& Zufriady, Z. (2021). Pengembangan Media Diorama Untuk Pembelajaran IPS Kelas IV Sekolah Dasar. Primary: Jurnal Pendidikan Guru $\begin{array}{lllll}\text { Sekolah Dasar, } & 10 & \text { (6), } & 1589-1598 . & \text { DOI: }\end{array}$ http://dx.doi.org/10.33578/jpfkip.v10i6.8556.

\section{PENDAHULUAN}

Belajar adalah suatu kegiatan individu dalam membentuk karakter. Karakter tersebut bisa didapat dalam aktivitas luar rumah, lingkungan tempat tinggal maupun dalam kegiatan sekolah. Menurut Slameto, (2015:2) Belajar adalah suatu proses usaha yang dilakukan seseorang untuk memperoleh suatu 
perubahan tingkah laku yang baru secara keseluruhan, sebagai hasil pengalamannya sendiri dalam interaksi dengan lingkungan.

Pembelajaran Ilmu Pengetahuan Sosial (IPS) dapat diartikan sebagai ilmu yang mempelajari pola interaksi anatara satu indivudu dengan individu yang lainnya sebagimana yang di ungkapkan oleh Nursid dalam Edy Surahman dan Mukmin (2017:3) mata pelajaran IPS memiliki tujuan mengembangkan potensi peserta didik agar peka terhadap masalah sosial yang terjadi di lingkungan masyarakat, memiliki sikap kepedulian dan memperbaiki ketimpangan yang telah terjadi, dan mampu mengatasi masalah sehari-hari dengan terampil baik untuk dirinya maupun orang sekitarnya yang ada dimasyarakat. Pembelajaran IPS memberi pengetahuan dan penerapan kepada siswa untuk menjadi warga negara yang baik dan sedini mungkin. (Ahmad Susanto, 2016). Mata pelajaran IPS merupakan sebuah nama mata pelajaran integrasi dari mata pelajaran sejarah,geografi, dan ekonomi serta mata pelajaran ilmu sosial lainnya. Sapriya (2017).

Dalam memenuhi tujuan-tujuan dalam pembelajaran, guru menjadi komponen utama dalam proses pembelajaran di kelas. Tujuan dari penggunaan Media ialah akan menjadi pusat perhatian siswa ketika guru memberikan informasi sehingga siswa akan memahami materi pembelajaran, ketika guru menggunakan media pula bisa membangkitkan motivasi belajar dan membuat pembelajaran menjadi efektif. Pada kenyataan saat ini guru kurang kreatif dalam pembuatan media pembelajaran dan mengolah pembelajaran dengan baik untuk dapat meningkatkan hasil belajar IPS. Kehadiran media pembelajaran dalam kegiatan belajar adalah sebagai alat bantu. Arief S. Sadiman, dkk.(2012:6) menyatakan bahwa media berarti perentara atau pengantar. Media adalah perentara atau pengantar pesan dari pengirim ke penerima pesan.Pada kenyataan yang terjadi guru hanya melakukan metode ceramah tanpa bantuan media, sehingga membuat pembelajaran yang monoton. Ketika guru menjelaskan pembelajaran tanpa bantuan media, maka anak tidak bisa mengkongkritkan materi yang dipelajari, namun dengan bantuan media tentunya guru akan mudah mengarahkan materi pembelajaran secara nyata atau kongkrit ketika pembelajaran berlangsung. Berdasarkan observasi penulis di kelas IV sekolah dasar di Indragiri Hilir (INHIL) di peroleh data siswa yang tidak fokus dan termotivasi dalam pembelajaran.

Berdasarkan permasalahan yang terjadi ketika pembelajaran tidak tertariknya siswa memperhatikan guru ketika menjelaskan sehingga menyebabkan rasa mengantuk dan bosan maka diperlukan media dalam proses pembelajaran, sehingga dengan bantuan media bisa menjadi peran penting baik bagi guru maupun untuk siswa, dan menarik perhatian siswa ketika pembelajaran berlangsung, hal ini tentunya agar bisa mendukung proses belajar dan mengajar mata pelajaran Ilmu Pengetahuan Sosial (IPS), penulis memilih penggunaan media diorama, karena penulis merasa bahwa untuk kelas IV sangat efektif ketika pembelajaran menggunakan media diorama. Diorama merupakan media tiga dimensi dalam ukuran kecil untuk menjelaskan suatu keadaan atau fenomena yang menunjukan aktivitas.Maka tujuan penelitian ini yaitu bagaimana mengembangkan media diorama untuk pembelajaran IPS Kelas IV Sekolah Dasar.

\section{KAJIAN TEORI Media}

Media dalam proses belajar-mengajar memiliki peran utama sebagai alat bantu mengajar dalam komponen metodologi yang diatur oleh guru. Melalui media yang digunakan maka diharapkan dapat mempertinggi kualitas proses pembelajaran yang pada akhirnya dapat mempengaruhi kualitas hasil belajar siswa. Guru hendaknya mengehatui bagaimana membuat pembelajaran menjadi efektif dan siswa mudah memahami pembelajaran dan tidak bersifat menghafal 
suatu bacaan. ( Dini Latifah. 2016)

Di dalam suatu pembelajaran, media sering diartikan sebagai alat-alat grafis, photografis yang berfungsi untuk menangkap, memperoleh, menyusun suatu informasi baik berupa visual maupun verbal (Rostina Sundayana 2015) media sangat memiliki peran ataupun kontribusi terhadap hasil belajar, dalam penggunaan media tersebut akan mendapat nilai tambah bagi seorang guru dalam proses pembelajaran, dengan adanya media guru bisa mempariasikan suatu pembelajaran agar anak tidak merasa bosan dan anak mampu melihat secara langsung gambar-gambar ataupun lukisan yang terdapat dalam media tersebut.

Kata media dalam pendidikan seringkali digunakan seacara bergantian dengan istilah alat bantu, diamana alat bantu ini akan memudahkan suatu pemahaman yang telah di transferkan kepada siswa agar pembelajaran lebih mudah untuk di terima. Media mempermudahkan guru dalam mencapai tujuan pembelajaran yang akan di capai. Melalui media hubungan komunikasi berjalan dengan mudah dan lancar dengan hasil yang maksimal dalam suatu tujuan yang ingin ditempuh. Sementara itu, Azhar Arsyad (2014) menggambarkan bahwa media tersebut merupakan sumber belajar yang memudahkan dalam berkomunikasi secara instruksional ataupun hal-hal yang membahas suatu pengajaran di dalamnya,tidak terlepas dari suatu gambar ataupun benda-benda yang ada dalam suatu media, hal tersebut juga harus memuat pula suatu perbuatan, sikap yang menanggung pada suatu pengajaran yang di berikan.

Kelas IV tergolong pada Pembelajaran pada anak sekolah dasar khusus nya untuk kelas IV masih membutuhkan suatu yang nyata sesuai dengan perkembangan peserta didik. Menurut teori piaget bahwa perkembangan peserta didik menjadi empat, yaitu priode sensorimotor, priode praoperasional, priode operasional dan priode operasional formal ( Syamsu Yusuf L.N dan Nani M. Sugandhi
2011). Pada tingkatan anak SD priode operasional, dimana pada priode ini dimulai dari anak berumur 7-11 tahun. Pada masa ini peserta didik masih diberikan contoh-contoh yang kongrit atau nyata sehingga anak mudah untuk memahami apa yang di berikan oleh guru. Oleh karena itu dengan bantuan media pembelajaran adanya hubungan timbal balik antara guru dan siswa. Tujuan media dalam pembelajaran yaitu mebuat suatu pembelajaran menjadi bermakna dan mudah dirasakan langsung oleh anak dengan keterlibatan siswa.Semakin konkret media yang diperhatikan oleh anak maka semakin bermaknalah suatu pembelajaran yang disampaikan guru.Pembelajaran yang di berikan oleh guru menanamkan suatu konsep dan karakteristik nilai esensial mata pelajaran.Untuk menjalankan suatu konsep maka sangat dibutuhkan media pembelajaran agar lebih mudah dalam memberikan pesan dan menciptakan hubungan timbal balik yang baik antara guru dan siswa. Media merupakan suatu proses awal keantusiasan siswa, maka rasa ingin tahu siswa timbul terhadap pembelajaran yang akan berlangsung.

\section{Diorama}

Diorama adalah media tiga dimensi kecil (mini) yang didukung dengan gambargambar atau lukisan yang menggambarkan pemandangan sebenarnya.Media diorama dikemas untuk memberikan kemudahan dalam menggunakannya. Diorama terdapat bentuk-bentuk objek atau sosok yang diletakan pada pentas berlatar belakang lukisan yang mendukung dengan pembelajaran.(Daryanto. 2010). Objek-objek yang ditampilkan pada diorama di tampilkan dengan warna-warna yang terang agar menarik perhatian dari siswa dalam proses belajar. Dalam pengemasan pada media diorama membuat bentuk-bentuk yang nyata agar anak mudah memahami apa yang di tampilkan.

Diorama memiliki fungsi dalam penggambaran terhadap suatu objek yang akan menjadi bahan pembahasan dalam 
penyampaian materi dalam pembelajaran. Dalam diorama juga bisa ditampilkan suatu adegan yang menggambarkan suatu kejadian yang benar-benar terjadi, baik mengenai sejarah, para tokoh, keadaan alam, maupun keadaan kota yang mendukung untuk proses belajar. Diorama adalah sebuah pemandangan tiga dimensi mini bertujuan untuk menggambarkan pemandangan sebenarnya. Diorama biasanya terdiri dari atas bentukbentuk sosok atau objek-objek di tempatkan di pentas yang berlatar belakang lukisan yang di sesuaikan dengan penyajian ( Nana Sudjana, dkk. 2016).

Dengan penggunaan media diorama maka akan tumbuh antusias atau minat siswa pada pembelajaran IPS sehingga adanya suatu keterkaitan siswa dalam memahami muncul. (Alfi Nurul Hidayati, dkk.2017). Bahan-bahan yang digunakan dalam pembuatan sangat sederhana dan mudah di temukan. Kelebihan dalam penggunaan diorama yaitu bisa digunakan berulang-ulang dan mudah disimpan. Diorama yang akan digunakan ini akan menggambarkan suatu kegiatan ekonomi yang ada dilingkungan tempat tinggal. Dilingkungan tersebut akan memanfaatkan sumber daya alam yang ada dan tentunya menghubungkan dengan jenis-jenis pekerjaan baik di desa sampai pada perkotaan. Diorama ini akan menampilkan bentuk nyata dari objek itu sendiri.

Ilmu Pengetahuan Sosial, yang sering disingkat dengan IPS, adalah ilmu pengetahuan yang mengkaji berbagai disiplin ilmu, IPS disekolah dasar mengetahuan pengetahuan awal dan keterampilan sebagai cara memberi pengetahuan dan penerapan kepada siswa untuk menjadi warga negara yang baik dan sedini mungkin. (Ahmad Susanto, 2016). Pembelajaran IPS tentu akan memberikan suatu perkembangan dalam konsep pemikiran yang kongkrit atau nyata yang ada dilingkungan masyarakat siswa tinggal, hal ini tentunya mengarahkan kepada bagaimana siswa nya bertanggung jawab atas bangsa dan negaranya.
Sapriya (2017) menyatakan bahwa mata pelajaran IPS merupakan sebuah nama mata pelajaran integrasi dari mata pelajaran sejarah,geografi, dan ekonomi serta mata pelajaran ilmu sosial lainnya. Dalam pembelajaran IPS tujuannya yaitu mempersiapkan siswa menjadi warga negara yang baik dan menguasai pengetahuan, keterampilan, sikap dan nilai yang dapat digunakan sebagai kemampuan dalam memecahkan masalah dalam kehiduapn seharihari yang dihadapi oleh peserta didik. Dari pembelajaran IPS yang terintegrasi dengan disiplin ilmu lainnya tentunya tidak akan terfokus pada satu bidang, bahkan akan membahas beberapa bidang dan pada bidang ekonomi akan membahas bagaimana perkembangan, permasalahan, dan faktorfaktornya.

\section{METODEPENELITIAN}

Jenis penelitian yang digunakan dalam penelitian ini adalah metode penelitian dan pengembangan (Research and Development). Model penelitian yang digunakan dalam penelitian adalah desain penelitian pengembangan model 4-D (Four D Models) menurut Thiagarajan Sivasaiman,dkk (1974). Hal ini meliputi 4 tahap yaitu tahap pendefenisisan (define), perancangan (design), pengembangan (develop) dan diseminasi (disseminate). Instrumen pengumpulan data menggunakan lembar validasi dan angket respon siswa dan guru. Lokasi uji coba produk dilakukan di Sekolah Dasar Negeri 018 Bagan Jaya Kecamatan Enok Kabupaten Indragiri Hilir.

Jenis data pada penelitian pengembangan ini yaitu berupa data kuantitatif.Data berupa kuantitatif diperoleh dari data validasi ahli media, ahli materi, respon guru dan siswa, data berupa informasi yang diperoleh dengan menggunakan angket, setelah produk di uji cobakan dalam pembelajaran.Penilaian yang dilakukan ialah ketepatan media dengan materi pembelajaran, ketepatan media dengan kondisi siswa, serta 
pengemasan yang baik, dan komponen lainnya yang bisa mendukung keefektifan media pembelajaran. Teknik pengumpulan data yang digunakan yaitu dengan menggunakan angket validasi ahli media dan validasi ahli materi dan praktisi yang dibuat secara skala likert. Dibawah ini pada Tabel 1 akan menjelaskan mengenai katagori kelayakan oleh ahli instrumen tes :

Tabel. 1 Katagori Validasi Ahli Materi

\begin{tabular}{clcc}
\hline No & \multicolumn{1}{c}{ Aspek } & Persentase & Kategori \\
\hline 1 & Kesederhanaan & 91.87 & Sangat Layak \\
2 & Penekanan & $96.87 \%$ & Sangat Layak \\
3 & Keterpaduan & $93.75 \%$ & Sangat Layak \\
& Rata-rata & $94.67 \%$ & Sangat Layak \\
\hline
\end{tabular}

Pada penelitian ini digunakan Skala Likert, skala ini digunakan untuk melihat respon siswa terhadap media yang dikembangkan. Langkah dalam analisis data ini yaitu mengumpulkan data mentah dan pemberian skor. Pada tabel 2 akan menjelaskan standar yang digunakan dapat mengetahui penilaian terhadap kategori penilaian terhadap media. Standar penilaian kelayakan uji oba respon guru dan siswa yaitu :

Tabel 2 katagori Uji Coba kelayakan media

\begin{tabular}{llll}
\hline No & Nilai & Rerata Skor & Kategori \\
\hline 1 & AA & $786-100$ & Sangat baik \\
2 & BB & $51-75$ & Baik \\
3 & CC & $26-50$ & Cukup \\
4 & DD & $0-25$ & Kurang Baik \\
\hline
\end{tabular}

(Sumber: modifikasi sugiono, 2019)

\section{HASIL DAN PEMBAHASAN}

Penelitian ini dilakukan berdasarkan model pengembangan menurut thiagarajan (1974). Hal ini memiliki 4 tahapan yaitutahappendefenisian(define), perancangan (design), pengembangan (develop) dan penyebaran ( disseminate).

\section{a. Pendefenisian (define)}

Pada tahap ini peneliti akan menentukan kebutuhan-kebutuhan yang akan diperlukan dalam proses pembuatan media serta mengumpulkan informasi-informasi yang berkaitan dengan produk yang akan dikembangkan oleh peneliti media diorama. Dalam tahap ini juga terbagi menjadi beberapa-langkah, yaitu:

1. Analisis awal
Analisis awal peneliti meanalisis keadaan guru dan siswa ketika melaksanakan proses belajar dan mengajar, kemudian membuat suatu rancangan yang sesuai dengan permaslahan dalam pengembangan media yang akan di ujicobakan dengan adanya suatu permasalahan maka peneliti akan mencari alternatif penyelesaian.

2. Analisis Peserta Didik

Tahap analisis peserta didik peneliti melakukan suatu pengamatan disaat pembelajaran, yaitu melihat bagaimana keadaan ataupun karakteristik dari siswa tersebut dan akan disesuaikan dengan media diorama yang akan dikembangkan.

3. Analisis Materi

Analisis materi dilakukan oleh peneliti 
dengan cara menyesuaikan media yang akan dikembangkan, maka peneliti akan memilih materi jenis-jenis pekerjaan yang ada di lingkungan tempat tinggal siswa. Kemudian ditampilkan dengan objek-objek yang menarik dan hampir nyata dengan keadaan sebenarnya.Materi yang digunakan yaitu jenisjenis pekerjaan yaitu KD 3.3 mengidenifikasi kegiatan ekonomi dan hubungannya dengan berbagai bidang pekerjaan serta kehidupan sosial budaya di lingkungan sekitar sampai provinsi.

4. Analisis Konsep

Pada tahap analisis ini peneliti melakukan perancangan materi dan penyesuaian media diorama yang akan di kembangkan hal ini memiliki tujuan untuk menyesuaikan materi dan media agar sejalan dengan tujuan dari pembelajaran.setelah menyesuaikan materi dengan media maka pengembangan media disesuaikan dengan keadaan tempat tinggal yang terdiri dari daerah pedesaan sampai perkotaan, sehingga media diorama yang dikembangkan menggambarkan daerah laut, pedesaan yang digambarkan dengan daerah pertanian dan perkotaan dengan keadaan perkotaan.

\section{b. Design (desain)}

Setelah dilakukan analisis tahap selanjutnya yaitu melakukan desain. Pada tahap desain atau perancangan penelitimengumpulkan terlebih dahulu bahan bacaan tentang pekerjaan, jenis-jenis pekerjaan, kekayaan alam, dan kegiatan ekonomi dari berbagai sumber untuk dijadikan referensi materi apa saja yang akan digunakan dalam media diorama. Adapun tahapantahapan yang akan dilakukan pada tahap perancangan adalah sebagai berikut:

1. Membuat Instrumen Penelitian

Instrumen yang dibuat digunakan untuk menilai kelayakan dan kevalidan dari media diorama untuk materi jenis-jenis pekerjaan dan kegiatan ekonomi.Adapun instrumen yang digunakan dalam penelitian ini adalah instrumen validasi ahli, praktisi dan instrumen respon siswa.instrumen validasi ahli materi memuat 9 butir pernyataan, instrumen ahli media memuat 9 pernyataan. Sedangkan pada istrumen uji coba produk di nilai dengan melihat bagaimana respon siswa melalui anket yang akan di berikan. Instrumen respon siswa dan guru dibuat untuk mengetahui kelayan dari media diorama.

2. Mempersiapkan Bahan dan Peralatan

Pada tahap ini peneliti akan mempersiapkan Bahan dan Peralatanmemilih bahan dan peralatan yang akan di gunakan dalm pembuatan media diorama kemudian merencanakan proses pengembangan yang dimulai dari merancang bentuk kotak, pembuatan rumah dan bangunan yang terbuat dari stik es krim dan ketas kokoru, pembuatan pohon kelapa, pembuatan tokoh jenis-jenis pekerjaan, pembuatan sawah dan rumputrumput, dan pembuatan sungai. Pada tahap ini peneliti melakukan konsultasi kepada dosen pembimbing mengenai bahan-bahan atau bahan-bahan yang mendukung dalam pembuatan media diorama. Merencanakan Proses Pengembangan Sebelum melaksanakan tindakan pengembangan, diperlukan sebuah perencanaan yang baik, agar suatu perencanaan memiliki tujuan yang membuat proses pengembangan berjalan dengan baik dan memperoleh hasil produk sesuai dengan keinginan, kebutuhan dan layak digunakan. Tahapan perencanaan proses pembuatan produk berupa media dimulai dari perencanaan proses pengembangan produk awal hingga uji coba kelayakan di lapangan.

\section{Tahap Pengembangan (Develop)}

Pada tahap pengembangan diperoleh produk akhir media diorama untuk pembelajaran IPS kelas IV sekolah dasar.Pada tahap ini menghasilkan suatuproduk yang telah divalidasi berdasarkan masukan yang diberikan validator ahli (expert appraisal).Tahap penilaian dari ahli merupakan tahap untuk melakukan validasi atau studi kelayakan dari media. rancangan produk yang dikembangkan.Pada tahap ini dilakukan oleh ahli media yang terdiri dari 3 validator, ahli materi 2 vaidator. Pada tabel 3 akan 

VOLUME 10 NOMOR 6 DESEMBER 2021

ISSN : 2303-1514 | E-ISSN : 2598-5949

Tabel 3. Data Validasi Ahli Materi

\begin{tabular}{c|lcc|}
\hline No & Aspek Penilaian & $\begin{array}{c}\text { Persentase Rata-Rata Tiap } \\
\text { Aspek }\end{array}$ & Katagori Validasi \\
\hline 1 & Kesederhanaan & $91.87 \%$ & Sangat Layak \\
2 & Penekanan & $96.87 \%$ & Sangat Layak \\
3 & Keterpaduan & $93.75 \%$ & Sangat Layak \\
& Rata-Rata & $94.67 \%$ & Sangat Layak \\
& Kelayakan & & \\
\cline { 2 - 4 }
\end{tabular}

Rata-rata kelayakan materi yang digunakan untuk kelayakan media diorama untuk pembelajaran IPS kelas IV sekolah dasar secara keseluruhan memperoleh persentase 94.67\% dengan katagori sangat layak. Berdasarkan analisis dan informasi dari semua aspek yang telah dianalisis serta dinilai oleh validator, maka perancangan produk yang dikembangkan yaitu media diorama untuk pembelajaran IPS kelas IV sekolah dasar, sudah sangat layak digunakan sebagai media pembelajaran pada materi kegiatan ekonomi yang berhubungan dengan jenis-jenis pekerjaan.Pada tabel 4 akan menjelaskan hasil presentasi dan katagori dari setiap aspek penilaian dari ahli media.

Tabel 4. Data Validasi Ahli Media

\begin{tabular}{llcc}
\hline No & Aspek Penilaian & Presentase Rata-Rata Tiap Aspek & Katagori Validasi \\
\hline 1 & Kelayakan isi & $87.50 \%$ & Sangat Layak \\
2 & Kebahasaan & $91.67 \%$ & Sangat Layak \\
3 & Penyajian & $91.67 \%$ & Sangat Layak \\
4 & Kegrafisan & $95.83 \%$ & Sangat Layak \\
& $\quad$ Rata-Rata Kelayakan & $\mathbf{9 1 . 6 7 \%}$ & Sangat Layak \\
\hline
\end{tabular}

\section{Uji Coba Terbatas}

Rata-rata kelayakan produk berupa media diorama yang dikembangkan secara keseluruhan pada data ahli media adalah 91.67\% dengan katagori sangat layak. Berdasarkan analisis dan informasi dari semua aspek yang dianalisis dan dinilai oleh validator ahli media, maka perancangan produk yang dikembngkan yaitu media diorama untuk pembelajaran IPS kelas IV sekolah dasar, sudah sangat layak digunakan pada pembelajaran.

Penilaian yang dilakukan untuk uji coba yaitu menggunakan instrumen berupa angket praktikalitas respon guru dan siswa terhadap penggunaan media pembelajaran diorama yang dikembangkan. Instrumen berupa angket praktikalitas respon guru terhadap media dan materi yang di uji cobakan terdapat 10 butir pertanyaan.Sedangan angket praktikalitas respon siswa diberikan kepada 23 siswa dengan 2 kelompok belajar dalam waktu satu kali uji coba masing-masing kelompok pembelajaran.Adapun hasil data dari repon guru dan siswa yang telah diolah dapat dilihat pada tabel dibawah ini. Pada tabel 5 akan menjelaskan hasil skor dari masing-masing praktikulasi guru dan siswa.

Tabel 5 hasil praktikalitas guru dan siswa

\begin{tabular}{ccc}
\hline No & Hasil Praktikalitas & Rata- Rata hasil skor Praktikalitas \\
\hline 1 & Praktikalitas respon Guru & $95 \%$ \\
2 & Praktikalitas respon siswa & $88.69 \%$ \\
3 & Rata-rata praktikalitas & $\mathbf{9 2 \%}$ \\
\hline
\end{tabular}


Berdasarkan hasil data dari validasi media, angket yang di isi oleh guru dan siswa dalam uji terbatas dapat disimpulkan bahwa media diorama layak digunakan untuk pembelajaran IPS kelas IV sekolah dasar terkhusus pada materi kegiatatan ekonomi dan hubungannya dengan jenis-jenis pekerjaan.

\section{Tahap Penyebaran}

Tahap penyebaran dilakukan untuk mempromosikan atau mengenalkan suatu produk hasil pengembangan tersebut kepada pengguna oleh individu, kelompok atau sisten.Produk yang sudah jadi maka di uji cobakan kepada siswa, hal ini bertujuan untuk mengetahui efektivitas produk yang dikembangkan.Selanjutnya setelah diterapkan, peneliti perlu mengamati hasil pencapain dari tujuan. Setelah adanya hasil dari pengamatan maka peneliti mengenalkan produk tersebut kepada guru dan menyampaikan panduan ataupun cara dalam menggunakan media diorama. Pada tahap penyebaran dilakukan FGD (Focus Groub Discussion) yang melibatkan 5 orang guru, berhubung masa pandemi covid-19 maka diskusi yang dilakukan melalui google meet, sebelum diskusi dimulai maka peneliti juga membuat Whatsapp Groub untuk mengirimkan link forum diskusi dan mengirim beberapa contoh gambar dari media diorama

\section{Pembahasan}

\section{AnalisisPengembangan Media}

Media adalah perentara atau pengantar pesan dari pengirim ke penerima pesan. Media merupakan bentuk prantara yang mampu mengarahkan suatu materi yang akan di capai hal ini didukung dengan pendapat Arief $S$. Sadiman, dkk(2012) bahwa media merupakan prantara atau pengantar. Media menjadi peran penting dalam kegiatan belajar agar anak menjadi senang ketika mengikuti pembelajaran. Pembelajaran pada siswa sekolah dasar khusus nya dikelas IV masih membutuhkan sesuatu yang nyata sesuai dengan apa yang dipikirkan oleh siswa tersebut. Pada dasarnya umur siswa kelas IV kurang lebih 10 tahun sehingga masih pada tahap perkembangan periode operasional sesuai dengan teori piaget dimana menurut Syamsu Yusuf L.N dan Nani M. Sugandhi (2011) peserta didik masih berpikir secara kongkrit atau nyata sehingga anak akan lebih mudah untuk memahami apa yang diberikan oleh guru. Oleh karena itu media yang sudah dikembangkan membuat pembelajaran menyenangkan dan adanya hubungan timbal balik antara guru dan siswa.

Media diorama adalah media tiga dimensi kecil (mini) yang diukung dengan gambar-gambar atau lukisan yang mengambarkan pemandangan yang sebenarnya.Diorama terdapat bentuk-bentuk objek atau sosok yang diletakan pada pentas berlatar belakang lukisan yang mendukung dengan pembelajaran.(Daryanto, 2010) Pada media diorama dengan materi kegiatan ekonomi dan hubungannya dengan jenis-jenis pekerjaan juga sesuai dengan pendapat Nana sudjana, dkk, (2016) bahwa media diorama terdiri dari bentuk atau sosok atau objek yang ditempatkan di pentas yang belatar belakang.

Penelitian pengembangan ini merupakan sebuah strategi yang cukup ampuh untuk memperbaiki praktik.Hal ini sejalan dengan pendapatnya Azhar Aryad (2014) yang menyatakan bahwa media memudahkan untuk berkomunikasi secara instruksional ataupun hal-hal yang membahas suatu pengajaran didalamnya.

Penelitian pengembangan adalah rangkaian proses atau cara-cara untuk mengembangkan suatu produk yang efektif dan berupa media, strategi, bahan-bahan pembelajaran yang bisa digunakan di sekolah, dan bukan menguji suatu teori. Berkaitan dengan permasalahan yang ada bahwa kurangnya penggunaan media diorama pada materi kegiatan ekonomi ini sangat cocok di terapkan di sekolah dasar Negeri 018 Bagan Jaya, karena sesuai dengan karakteristik siswa di kelas IV dan membahas tentang jenis-jenis pekerjaan yang diawali dengan materi yang ada dilingkungan tempat tinggal siswa, hal 
inilah yang membuat suatu pembelajaran adanya timbal balik anatara siswa dan guru, dengan mengamati media dan jenis pekerjaan yang ada anak akan mampu menyampaikan apa yang mereka pahami atau lihat dilingkungan tempattinggalnya. Berdasarkan hasil validasi media diorama dari ahli materi di peroleh skor rata-rata sebesar $94.67 \%$ dengan katagori sangat layak, berdasarkan hasil data yang telah diperoleh bahwa materi yang di gunakan pada media sangat mendorong keinginansiswa untuk belajar serta memberikan informasi yang mereka miliki. sedangkan hasil dari validasi media diorama dari ahli media di peroleh skor sebesar 91.67\% dengan katagori sangat layak. Sehingga berdasakan hasil tersebut secara keseluruhan media diorma yang dikembangkan oleh peneliti sangat layak digunakan pada siswa sekolah dasar dan hal ini juga sesuai dengan penelitian sebelumnya oleh Miftah Devi Amelia, dkk (2017) tentang suatu pembelajaran layak digunakan di sekolah dasar dalam meningkatkan hasil belajar. Menurut Dini Latifah (2016) media diorama dapat meningkatkan hasil belajar bahasa arab siswa di MTs Yogyakarta.

\section{Kelayakan Media Diorama}

Media diorama yang akan ditampilkan berbentuk kotak yang terbuat dari triplek. Media ini ketika dibuga maka bagian masingmasing sisi terdapat gambar atau latar dari jenis-janis pekerjaan dan hubungannya dengan kegiatan ekonomi. Kelayakan media diorama yang dikembangkan dilihat pada data yang diperoleh dari validator ahli dan uji coba produk respon guru dan siswa. Ditemukan media diorama yang layak digunakan sebagai media pembelajaran tema lingkungan tempat tinggalku kelas IV SD semester II dengan cara dikembangkan media diorama bisa mengkongkritkan pemahaman siswa. Hal ini sejalan dengan pendapat Yadi Munadi (2013) bahwa media diorama adalah pemandangan tiga dimensi dalam ukuran kecil untuk menggambarkan atau melihatkan aktivitas atau fenomena yng terjadi. Media diorama memiliki perlengkapan yang dapat membantu siswa seperti: pewarnaan media yang menarik, provorsi objek penunjang lainnya sesuai dengan posisinya, bahan yang digunakan tahan lama sehingga media diorama dapat digunakan dalam waktu yang panjang dan aman bagi siswa. Dengan adanya penggunaan media diorama saat belajar dapat menambah konsentrasi dan menghidupkan suasana pembelajaran, sehingga pembelajaran menjadi lebih aktif dan interaktif.Keunggulan dari media diorama dapat menumbuhkan minat belajar siswa, siswa berlatih untuk meningkatkan kreativitas, kemandirian dan menumbuhkan suasana kelas yang aktif.Pada penelitian Fitriani Handayani (2018) sebelumnya manyatakan bahwa media diorama praktis dalam penggunaannya. Media diorama ini akan mudah untuk dibawa oleh guru ataupun siswa dan mudah untuk disimpan sehingga bisa digunakan berulangkali. Dengan menggunakan media diorama minat siswa dalam belajar materi kegiatan ekonomi dan hubungannya dengan jenis pekerjaan dapat meningkat dan siswa mendapat wawasan baru.

Pada penelitian sebelumnya yang dilakukan oleh Nur Fitri Ulfiani( 2017) bahwa Media diorama sangat membantu untuk mengkongkritkan pamahaman siswa terhadap materi yang disampaikan oleh guru, hal ini sesuai dengan keadaan siswa pada kela IV pada tahap perkembangan kongkrit, dimana siswa masih memahami suatu keadaan ketika anak tersebut dilihatak suatu keadaan pada keadaan ataupun aktivitas yang nyata. Media diorama sangat layak digunakan pada tahap perkembangan kongkrit sesuai dengan penelitian Miftah Devi Amelia, dkk(2017) dan penelitian Dini Latifa (2016) dimana media diorama ini layak digunakan dalam menyampaikan materi pembelajaran yang mendorong siswa untuk lebih fokus ketika pembelajaran berlangsung.

\section{SIMPULAN DAN REKOMENDASI}

Penelitian dan pengembangan yang dilakukan bertujuan untuk menghasilkan 
produk media diorama pada pembelajaran IPS dengan materi kegiatan ekonomi dan hubungannya dengan jenis pekerjaan pada kelas IV sekolah dasar. Adapun produk tersebut berupa media tiga dimensi yang menggambarkan atau menjelaskan suatu keadaan atau kejadian suasana lingkungan tertentu dalam bentuk kotak.

Berdasarkan hasil validasi yang dilakukan oleh ahli materi, ahli media,ahli praktisi serta uji terbatas didapatkan hasil sebagai berikut: (1) Validasi oleh ahli materi terhadap media diorama adalah 91,67\% dengan katagori sangat layak ; (2)Validasi oleh ahli media terhadap media diorama adalah 94.67\% dengan katagori sangat layak ; (3) Validasi oleh praktisi terhadap media diorama adalah $95 \%$ dengan katagori sangat layak;(4) Validasi uji coba terbatas terhadap media diorama adalah $88.69 \%$ dengan katagori sangat layak

\section{Saran}

Berdasarkan kesimpulan diatas, maka peneliti mengajukan saran-saran sebagai berikut: (1) media diorama ini dapat dikembangkan lagi untuk materi pembelajaran IPS lainnya, namun perlunya suatu analisis terhadap kurikulum serta analisis dan karakteristik siswa terlebih dahulu serta pemilihan bahan yang baik; (2) penggunaan triplek yang dipilih hendaknya berdiameter tebal agar mudah dan tidak pecah ketika pemasangan engsel pada masing-masing sisi serta adanya pengamplasan dibagian pinggir agar kelihatan halus.

\section{DAFTARPUSTAKA}

Amelia, M. D. (2017). Pembelajaran IPS di sekolah Dasar. Jurnal Penelitian Pendidikan, 20, 188.
Arsyad, A. (2014). Media Pembelajaran ( Edisi Revisi). Jakarta: PT RajaGrafindo Persada

Daryanto. (2010). Media Pembelajaran. Yogyakarta: Gava Media.

Latifah, D. (2016). Pengembangan Media Diorama untuk meningkatkan Hasil Belajar Arab di kelas VII MTsN Yogyakarta 1. 2. Hlm.255

Nursyid. (2018). Pembelajaran Ilmu Pengetahuan Sosial pada Anak. Jakarta 2 (1). Hlm 125

Sadiman, A. (2012). Media Pendidikan ( Pengertin, Pengembangan, dan Pendidikan). Depok: PT Rajgrafindo Persada.

Sudjana, N. (2016). Penilaian Hasil Belajar Mengajar. Bandung: PT Remaja Rosdakarya

Sugiyono. (2015). Metode Penelitian Pendidikan(p.407). Bandung: Alfabeta

Sugiyono. (2019). Metode Penelitian Pendidikan. Bandung: Alfabeta

Susanto, A. (2012). Teori Belajar \& Pembelajaran di Sekolah Dasar.J akarta: Prenamedia Groub

Sapriya. (2017). Pendidikan IPS konsep dan pembelajaran. Bandung: PT Remaja Rosdakarya

Slameto. (2015). Belajar dan Faktor-Faktor yang Mempengaruhinya. Jakarta: PT. Rineka Cipta.

Thaigarajan. Sivasailam,dkk. (1974). Instructional Development for Training Teacher of Exceptional Children.Washinton DC: Nasional Center for Improvement Educational System.

Yusuf, S., Nani, M., \& Sugandhi. (2011). Perkembangan Pesera Didik. Jakarta: PT RajaGrafindo Persada. 